\title{
Beta-adrenoreceptor blocking drugs and thyroid hormones in hyperthyroid subjects
}

\author{
M. K. JONES \\ M.B., M.R.C.P. \\ D. R. OWENS
M.B.
}

J. BIRTWELL

M.B., M.R.C.P.

G. R. JONES

M.B., M.R.C.P.

\author{
M. LEWIS \\ M.B. \\ Departments of Medicine and Pharmacology, University Hospital of Wales, Heath Park, Cardiff
}

\begin{abstract}
Summary
Serum thyroid hormone concentrations were measured before and during 10 days' treatment with atenolol (200 mg/day), acebutolol (400 mg/day), oxprenolol $(160 \mathrm{mg} /$ day) and propranolol (160 $\mathrm{mg} /$ day) in 24 hyperthyroid patients. During propranolol treatment serum triiodothyronine $\left(T_{3}\right)$ concentrations fell significantly $(P<0.05)$ but there was no change in thyroid hormone concentrations in the other groups although all patients reported a symptomatic improvement.
\end{abstract}

\section{Introduction}

Beta-adrenoreceptor blocking drugs are widely used in the treatment of hyperthyroidism. Propranolol causes a fall in serum triiodothyronine $\left(\mathrm{T}_{3}\right)$ concentrations in hyperthyroid patients, probably via an action on the peripheral conversion of thyroxine $\left(T_{4}\right)$ to $T_{3}$ and reverse $T_{3}\left(\mathrm{rT}_{3}\right)$ (Lotti et al., 1977; Kallner, Ljunggren and Tryselius, 1978; Feely et al., 1979). The action of $\beta$-adrenoreceptor blocking agents other than propranolol on circulating thyroid hormones in hyperthyroidism has not been widely studied, although the present authors have described the lack of effect of those drugs possessing the subsidiary property of partial agonist activity (ISA) (Jones, John and Jones, 1980). In order to provide further evidence on this point a comparative study of the effect of 4 different $\beta$-adrenoreceptor blocking agents in these patients has been made.

\section{Subjects and methods}

Twenty-four untreated hyperthyroid women (aged

Correspondence: M. K. Jones, M.R.C.P., Senior Medical Registrar, Department of Medicine, University Hospital of Wales, Heath Park, Cardiff, Great Britain.
24-55 years) were studied as out-patients after giving their informed consent. Hyperthyroidism was diagnosed in each subject by clinical criteria, by raised serum levels of $T_{4}$ and $T_{3}$ and by increased thyroid uptake of ${ }^{131} \mathrm{I}$. Patients were assessed clinically before and 10 days after treatment. The patients were divided into 4 groups of 6 , receiving either atenolol $(200 \mathrm{mg} /$ day), or acebutolol (400 $\mathrm{mg} /$ day $)$, or oxprenolol $(160 \mathrm{mg} /$ day $)$ or racemic propranolol $(160 \mathrm{mg} /$ day $)$ in a twice daily dosage for 10 days. No other drug was given. Venous blood samples were taken on 2 occasions before treatment and at one, 2, 4, 7 and 10 days after the first dose.

All blood samples were obtained from an antecubital vein at 10.00 hours after an overnight fast and $30 \mathrm{~min}$ bed rest. Samples were centrifuged promptly and serum stored at $-20^{\circ} \mathrm{C}$ until assayed. $\mathrm{T}_{4}$ (normal range $55-150 \mathrm{nmol} / \mathrm{l}$ ) was measured by radioimmunoassay using a method based on that of Challand, Ratcliffe and Ratcliffe (1975). $T_{3}$ (normal range $1.3-3.5 \mathrm{nmol} / \mathrm{l}$ ) was measured by solid phase radioimmunoassay (Immophase, Corning Medical, Halstead, Essex) and vacant thyroid hormone binding sites were assayed by Thyopac- 3 test $\left(T_{3} R U\right)$ (normal range 92-117) (Radiochemical Centre, Amersham, Bucks). Free thyroxine index $\left(\mathrm{FT}_{4} 1\right.$, normal range 55-145 $\mathrm{nmol} / \mathrm{l})$ and free triiodothyronine index $\left(\mathrm{FT}_{3} 1\right.$, normal range 1.4-3.7 nmol/l) were expressed as $100 \times T_{4}$ or $T_{3}$ divided by the $T_{3} R U$ value. At the mid-point of the normal ranges the coefficients of variation for the assays of $T_{4}, T_{3}$ and $\mathrm{T}_{3} \mathrm{RU}$ were $8.0 \%, 8.5 \%$ and $1.7 \%$ respectively. For each index all samples were measured in one assay run. Data are presented as mean values \pm standard error and compared by Student's $t$-test for paired data. 


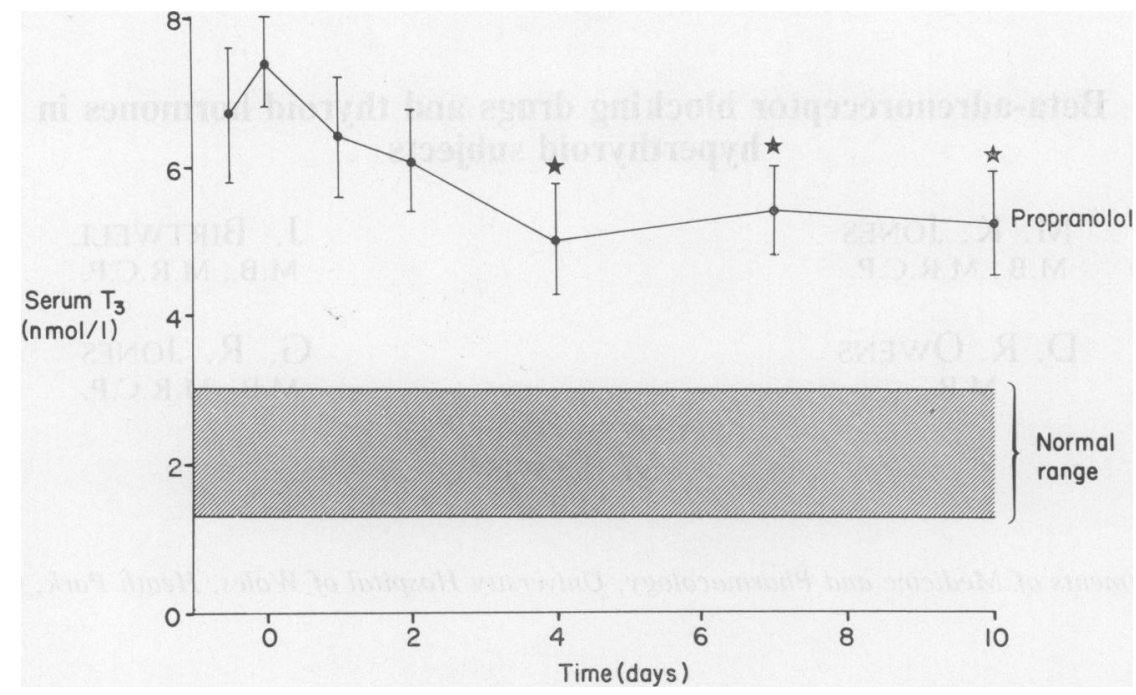

FIG. 1. Serum triiodothyronine $\left(\mathrm{T}_{3}\right)$ concentrations (means \pm s.e. mean) in 6 hyperthyroid patients before and at one, 2, 4, 7 and 10 days after propranolol treatment $\left(160 \mathrm{mg} /\right.$ day). ${ }^{*}$ Indicates a significant $(P<0.05)$ difference from corresponding measurements before propranolol treatment.

\section{Results}

Serum $T_{3}$ values fell significantly $(P<0.05) 4$ days after starting propranolol and this was sustained at 10 days (Fig. 1). Changes in $\mathrm{FT}_{3} \mathrm{I}$ values reflected those seen in $T_{3}$ concentrations but there was no significant change in $\mathrm{T}_{4}$ or $\mathrm{FT}_{4} \mathrm{I}$ in the group treated with propranolol.
There was no significant change in thyroid. hormone levels in the other groups (Fig. 2). Resting $\overrightarrow{0}$ pulse rate was lowered $(P<0.05)$ in the 4 grows and all patients reported a symptomatic improge ment in terms of excessive sweating, nervousness preference for cold and general wellbeing after 10 days' treatment.

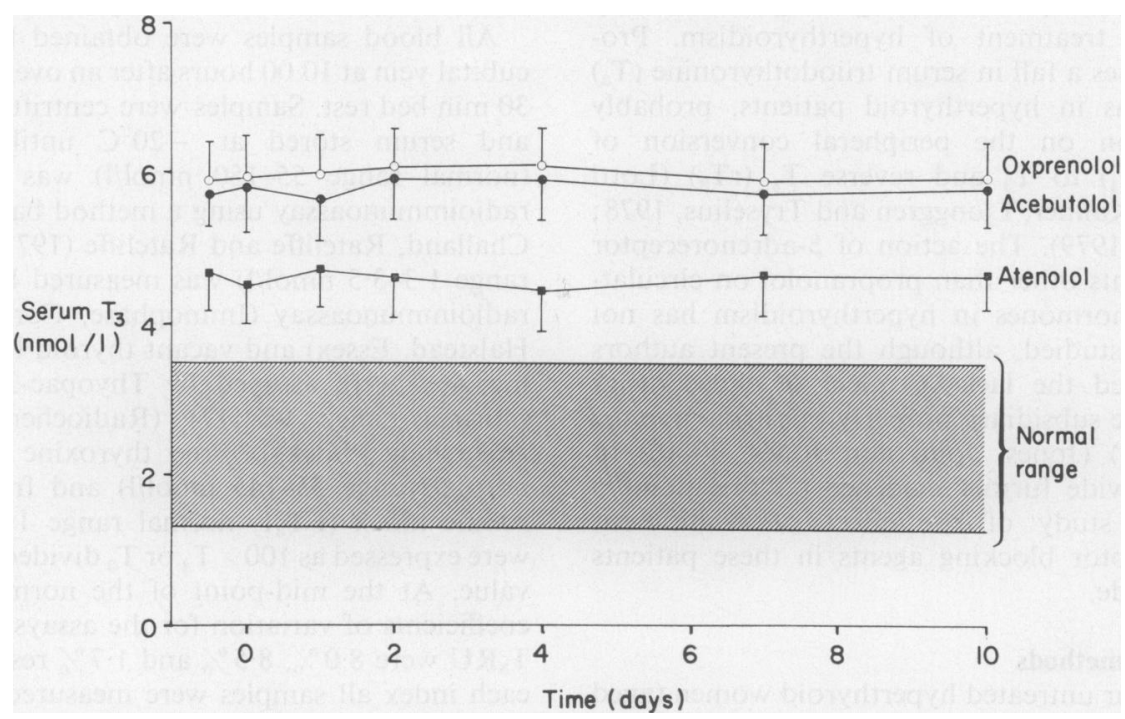

FIG. 2. Serum triiodothyronine $\left(T_{3}\right)$ concentrations (means \pm s.e. mean) in 3 groups of 6 hyperthyroid patients before and at one, 2, 4, 7 and 10 days after atenolol $(200 \mathrm{mg} /$ day), acebutolol $(400 \mathrm{mg} /$ day) and oxprenolol (160 $\mathrm{mg} /$ day) treatment. 


\section{Discussion}

Propranolol caused a significant $(P<0.05)$ and sustained fall in serum $T_{3}$ concentrations to approximately $75 \%$ of pre-treatment values while atenolol, acebutolol and oxprenolol had no effect on circulating thyroid hormones. The mechanism by which propranolol exerts this action is unclear. It differs from the other drugs studied in that neither is it cardioselective nor does it have ISA (Fig. 3). The subsidiary property of ISA cannot explain the lack of effect of acebutolol and oxprenolol since atenolol, which does not possess ISA, also had no effect. It is possible that other non-selective $\beta$ adrenoreceptor blocking drugs without ISA could lower serum $T_{3}$ concentrations in the same way as propranolol.

\begin{tabular}{|l|c|c|c|c|}
\cline { 2 - 5 } \multicolumn{1}{c|}{} & Atenolol & Acebutolol & Propranolol & Oxprenolol \\
\hline Cardioselectivity & + & + & $\bigcirc$ & $\bigcirc$ \\
\hline $\begin{array}{l}\text { Partıal agonıst response } \\
\text { (IS A) }\end{array}$ & $\bigcirc$ & + & $\bigcirc$ & ++ \\
\hline $\begin{array}{l}\text { Membrane stabilizıng } \\
\text { activity (M S A) }\end{array}$ & $\bigcirc$ & + & ++ & + \\
\hline
\end{tabular}

FIG. 3. Comparison of subsidiary properties of atenolol, acebutolol, propranolol and oxprenolol. + indicates subsidiary property present, $O$ indicates subsidiary property absent.

The other subsidiary property of membrane stabilizing activity (MSA) must also be considered when attempting to explain the action of propranolol on serum $T_{3}$ levels. It has been suggested from a study of euthyroid and hypothyroid subjects receiving $T_{4}$ that this effect of propranolol is related to its MSA (Heyma et al., 1980). In the present study, however, neither acebutolol nor oxprenolol lowered serum $T_{3}$ concentrations and, although these drugs are less effective than propranolol as membrane stabilizing agents, both as local anaesthetics and in their action on intracellular cardiac potentials (Vaughan-Williams and Papp, 1970; Basil et al., 1973), a fall would have been expected if the presence of MSA was important.

No clinical advantage was found in the patients' response to propranolol when compared with the other $\beta$-adrenoreceptor blocking drugs. Despite initial concern over the use of $\beta$-adrenoreceptor blocking agents with ISA in the treatment of hyperthyroidism (Turner, 1974), this finding is supported by the results of recent studies comparing propranolol with various classes of cardioselective $\beta$-adrenoreceptor blocking agents (Nelson and McDevitt, 1975; Murchison et al., 1976; Nilsson et al., 1979; Murchison, How and Bewsher, 1979). The therapeutic relevance of the fall in serum $T_{3}$ concentrations in hyperthyroid patients on propranolol is not established.

\section{Acknowledgments}

We wish to thank Dr J. N. Harris-Jones (Singleton Hospital, Swansea) and Dr J. H. Lazarus (University Hospital of Wales, Cardiff) for allowing us to carry out these clinical studies on patients under their care, and Dr R. John (Department of Medical Biochemistry, University Hospital of Wales, for carrying out the $T_{4}, T_{3}$ and $T_{3} R U$ assays.

\section{References}

Basil, B., Jordan, R., Lovelless, A.H. \& Maxwell, D.R. (1973) $\beta$-adrenoreceptor blocking properties amd cardioselectivity of M and B 17, 803A. British Journal of Pharmacology, 48, 198.

Challand, G.S., Ratcliffe, W.A. \& Ratcliffe, J.G. (1975) Semi-automated radioimmunoassay for total serum thyroxine and triiodothyronine. Clinica chimica acta, 60, 25.

Feely, J., Isles, T.E., Ratcliffe, W.A. \& Crooks, J. (1979) Propranolol, triiodothyronine, reverse triiodothyronine and thyroid disease. Clinical Endocrinology, 10, 431.

Heyma, P., LaRkins, R.G., Higginbotham, L. \& Kong WAH, NG. (1980) D-Propranolol and DL-propranolol both decrease conversion of L-thyroxine to L-triiodothyronine. British Medical Journal, 281, 24.

Jones, M.K., JoHN, R. \& Jones, G.R. (1980) The effect of oxprenolol and acebutolol on thyroid hormones in hyperthyroid subjects. Clinical Endocrinology, 13, 343.

Kallner, G., LuUnggren, J.G. \& Tryselius, M. (1978) The effect of propranolol on serum levels of $T_{4}, T_{3}$ and reverse- $\mathrm{T}_{3}$ in hyperthyroidism. Acta medica scandinavica, 204, 35.

lotti, G., Delitala, G., Devilla, L., Alagna, S. \& Masala, A. (1977) Reduction of plasma triiodothyronine $\left(\mathrm{T}_{3}\right)$ induced by propranolol. Clinical Endocrinology, 6, 405.

Murchison, L.E., Bewsher, P.D., Chesters, M.I. \& FERRIER, W.R. (1976) Comparison of propranolol and practolol in the management of hyperthyroidism. British Journal of Pharmacology, 3, 273.

Murchinson, L.E., How, J. \& Bewsher, P.D. (1979) Comparison of propranolol and metoprolol in the management of hyperthyroidism. British Journal of Clinical Pharmacology, 8, 581.

Nelson, J.K. \& McDevitT, D.G. (1975) Comparative trial of propranolol and practolol in hyperthyroidism. British Journal of Clinical Pharmacology, 2, 411.

Nilsson, O.R., KarlberG, B.E., Kagedal, B., Tegler, L. \& Almovist, S. (1979) Non-selective and selective $\beta$-1adrenoreceptor blocking agents in the treatment of hyperthyroidism. Acta medica scandinavica, 206, 21.

TURNER, P. (1974) Beta-adrenoreceptor blocking drugs in hyperthyroidism. Drugs, 7, 48.

Vaughan-Williams, E.M. \& PaPP, J.G.Y. (1970) The effect of oxprenolol on cardiac intracellular potentials in relation to its anti-arrhythmic, local anaesthetic and other properties. Postgraduate Medical Journal (Nov. Suppl.), 22. 